J. Lake Sci. (湖泊科学) , 2013, 25(1): 73-81

http: //www.jlakes.org. E-mail: jlakes@niglas.ac.cn

(C) 2013 by Journal of Lake Sciences

\title{
基于卫星资料的北京陆表水体的热环境效应分析"
}

\author{
刘勇洪 ${ }^{1}$, 轩春怡 ${ }^{1,2}$, 权维俊 ${ }^{1}$ \\ ( 1 : 北京市气候中心, 北京 100089$)$ \\ ( 2 :兰州大学大气科学学院,兰州 730000)
}

\begin{abstract}
摘 要: 应用不同分辨率的卫星资料对北京水体类别、密云水库及城区典型水体的热环境特性及城区水体对其周围热环 境影响进行研究分析. 利用 2006 年的 MODIS 卫星地表温度产品对北京不同类型的地表温度研究显示: 就北京四季平均 状态来说,水体类别在白天具有降温作用, 在秋季和冬季夜晚具有保温作用,在春季和夏季夜晚具有降温作用. 利用 NOAA/AVHRR卫星资料对密云水库的研究分析显示: 密云水库在夏季白天具有“冷湖效应”,夜晚具有“暖湖效应”; 密云 水库在冬季未结冰时白天和夜间具有“暖湖效应”, 在结冰时白天具有“冷湖效应”而晚上无冷暖效应. 利用 FY- $3 \mathrm{~A} / \mathrm{MERSI}$ NOAA/AVHRR 和 Landsat-TM 卫星资料对北京城区典型水体监测结果显示: 城区水体不会有热岛现象出现,大面积的水体 易出现 “冷岛效应”. 利用 2008 年夏季 Landsat-TM 卫星资料对城区典型水体和天坛公园绿地 $500 \mathrm{~m}$ 范围内的建筑地温研 究分析显示: 城区水体温度明显低于天坛公园绿地. 城区各水体周边 $100 \mathrm{~m}$ 范围内建筑区地温平均下降 $1.2^{\circ} \mathrm{C} ; 100 \sim 200 \mathrm{~m}$ 内下降 $0.6^{\circ} \mathrm{C} ; 200 \sim 300 \mathrm{~m}$ 内下降 $0.4^{\circ} \mathrm{C}, 300 \mathrm{~m}$ 范围外无明显变化. 天坛公园绿地周边仅 $100 \mathrm{~m}$ 内的建筑区地温下降,下 降值为 $0.4^{\circ} \mathrm{C}$. 这些研究结果表明: 卫星资料能有效监测水体的热环境效应, 大面积的水体是降低城市地表热岛效应的重 要来源, 北京城区水体对周边最大 $300 \mathrm{~m}$ 范围内的建筑区地表温度具有降温效应.
\end{abstract}

关键词: 水体;热环境效应;密云水库;建筑区; 北京

\section{Thermal environment effect of land surface water bodies in Beijing based on satellite data}

\author{
LIU Yonghong ${ }^{1}$, XUAN Chunyi ${ }^{1,2}$ \& QUAN Weijun ${ }^{1}$ \\ (1: Climate Center, Beijing Meteorological Bureau, Beijing 100089, P. R. China) \\ (2: College of Atmospheric Sciences, Lanzhou University, Lanzhou 730000, P. R. China)
}

\begin{abstract}
Satellite data in different resolutions were used to study thermal environment characters of water body type, Miyun Reservoir, typical urban water bodies and their impacts on the environment around Beijing. The research of different land-use types using MODIS land surface temperature product indicated that at average seasonal time scale water body type of Beijing had temperature-decreasing effect during the daytime, while it had temperature-increasing effect in the night, of autumn and winter, and had temperature-decreasing effect in the night of spring and summer. The analysis of Miyun reservoir using NOAA/AVHRR data showed that it had cold lake effect in the daytime and warm lake effect in the night in summer. On no-freezing condition in winter, Miyun Reservoir had warm lake effect during the day and night. But on freezing condition it had cold lake effect during the day and had no warm or cold island effect during the night. The monitoring results of typical urban water bodies in Beijing using FY-3A/ MERSI, NOAA/AVHRR and Landsat-TM data indicated that water bodies of urban had no heat island effect and the larger area water bodies had strong cold island effect. The analysis of land surface temperature of buildings within 500 meters to typical urban water bodies and Temple of Heaven Park, respectively, indicated that water bodies had lower temperature than the green space of Temple of Heaven Park. Average ground surface temperature of buildings decrease by $1.2,0.6$ and $0.4^{\circ} \mathrm{C}$ with the distance away from water bodies less than $100 \mathrm{~m}, 100-200 \mathrm{~m}$ and $200-300 \mathrm{~m}$, respectively. Green space of Temple of Heaven Park had cooling effect only within $100 \mathrm{~m}$ distance with the surface temperature decreased by $0.4^{\circ} \mathrm{C}$. The results showed that satellite data could be effectively used to monitor thermal environment of these water bodies, and large area of water bodies were important sources of slowing down urban heat island effect. The maximum distance of cooling effect of water bodies on building around was $300 \mathrm{~m}$ in the urban areas of Beijing.
\end{abstract}

* 国家自然科学基金项目 (41175015)、国家重点基础研究发展规划项目 (2010CB428506) 和北京市气象局“城市边 界层观测分析与精细模式”创新团队项目联合资助. 2012-02-08 收稿;2012-06-09 收修改稿. 刘勇洪,男,1974 年生, 高级工程师; E-mail :lyh7414@ 163. com. 
Keywords: Water body; thermal environment effect; Miyun Reservoir; building area; Beijing

城市化是人类社会发展的必然趋势. 城市化进程中: 建筑物、沥青或水泥马路等不透水下垫面逐渐代替 了原有的农田、森林、河流、湖泊等自然地表覆盖, 伴随着下垫面特征的这种巨大变化, 城市的近地层大气结 构和微气象环境也发生相应的变化 ${ }^{[1-2]}$. 如城区水体、绿地面积的减少会使气温升高、湿度降低 ${ }^{[3]}$, 但另一方 面, 如果在城市区域增加水体、绿地等自然地表, 则有利于城市的减温、增湿 ${ }^{[4-5]}$, 有利于降温及减缓城市热 岛效应 ${ }^{[6-7]}$. 由于水体的辐射特征和热力特征与周围类型有显著差异, 显示出与周边不同的小气候或影响着 周边的局地气候, 傅抱璞分析了不同自然条件下的水体气候效应 ${ }^{[8]}$, 毛以伟等分析了三峡水库水体的热气 候效应 ${ }^{[9]}$, 吕雅琼等和赵林等分别研究了青海湖和金塔绿洲水库的冷 (暖) 湖效应 ${ }^{[10-11]}$. 而近年来由于城市 发展中城市热岛效应突出问题, 城市中水体对局地气候及人居环境的影响近年来也引起关注 ${ }^{[12]}$. 杨凯等分 析了上海中心城区 6 处不同类型的城市河流及水体周边的小气候效应, 并探讨了主要影响因素 ${ }^{[13]}$. 李书严 等研究了水体的微气候效应, 研究结果表明城市中的水体对其周边的小气候有着明显的调节作用, 水体的 面积和布局是影响小气候效应的重要因素 ${ }^{[14]}$. 轩春怡等研究表明无论分散型或集中型布局, 城市水体面积 的增加, 都在一定程度上使城市气温降低、湿度增加、平均风速增大. 比较而言, 分散型水体布局对城市区域 微气象环境的影响更为显著 ${ }^{[15]}$. 上述研究结果多集中于城区水体及周边站点的“点” 观测或数值模拟, 对城 市“面” 状区域水体的微环境效应研究得较少, 而遥感技术则提供了一种面向空间区域研究城市水体热环境 效应的有效途径. 遥感监测水体热环境的原理是基于不同地物在远红外波段具有辐射差异, 通过远红外传 感器对城市地表 (含水体) 温度进行大面积观测而得到的地物热量空间差异分布, 从而可以对城市水体及其 周边环境进行监测与分析. 国内利用卫星资料研究水体的热环境效应的研究较少, 本文将针对北京大型水 体 (以密云水库为例) 及城区重要水体, 利用卫星遥感资料开展水体的热环境效应分析, 分析其自身的热环 境特征及其对周边区域热环境的影响,对城市规划及减缓热岛效应方面具有借鉴意义.

\section{1 资料和方法}

\section{1 资料}

为研究北京不同尺度水体的热环境效应,本文采用具有高时间分辨率的中粗分辨率卫星资料 250 $1000 \mathrm{~m}$ 分辨率) 和高空间分辨率的卫星资料 (30 120 m 分辨率) 进行地表水体热环境分析.

中粗分辨率资料主要采用 NOAA/AVHRR、MODIS/Terra 和 FY-3A 卫星资料. 其中 NOAA/AVHRR 卫星 主要利用 $1 \mathrm{~B}$ 数据的第 4 和第 5 热红外通道亮温来分析地表热场, 空间分辨率为 $1 \mathrm{~km}$ 左右 ${ }^{\left[{ }^{[6]}\right.}$. 本文选用 2006 年 8 月 21 日、2009 年 11 月 17 日和 18 日、2011 年 2 月 15 日的 NOAA/AVHRR 1B 数据. EOS/MODIS 卫 星资料则采用 $8 \mathrm{~d}$ 合成的 MODIS 地表温度产品 (MOD11 A2), 空间分辨率为 $1 \mathrm{~km}^{[17]}$, 本文选用 2006 年全年 的 $8 \mathrm{~d}$ 合成的 MODIS 地表温度产品数据. FY-3A 卫星利用中分辨率光谱成像仪 (MERSI) 第 5 热红外通道估 算地表温度,空间分辨率为 $250 \mathrm{~m}^{[18]}$, 本文选取 2009 年 6 月 25 日的 FY-3A/MERSI 数据.

高分辨率卫星资料主要采用 Landsat5-TM 的第 $1 \sim 5$ 波段和第 7 波段提取水体及其他土地利用类型, 空 间分辨率为 $30 \mathrm{~m}$, 利用第 6 热红外通道来估算陆面地表温度, 空间分辨率为 $120 \mathrm{~m}^{[19]}$. 本文选用北京地区 2008 年 8 月 2 日 10 时 40 分过境的晴空清晰无云的 Landsat5-TM 来分析北京城区水体热环境.

\section{2 研究方法}

1.2. 高分辨率卫星资料地表温度的反演 利用高分辨率卫星 Landsat5-TM 数据反演陆地表面温度主要分为两 大步骤: (1) 计算辐射亮温; (2) 利用辐射亮温计算地表温度. 首先利用 Landsat5-TM 的定标系数 (Gain 和 Bias) 将 原始 $D N$ 值转换为大气层顶太阳辐亮度 $(L)$, 定标系数由 USGS 的 Landsat Project 提供 ${ }^{[19]}$, 计算公式为:

$$
L=\text { Gain } \cdot D N+\text { Bias }
$$

式中, $D N$ 为像元灰度值, Gain 为增益, Bias 为偏移值. 再利用下面的公式将其转化为亮度温度 ${ }^{[19]}$ :

$$
T_{\mathrm{b}}=K_{2} / \ln \left(1+K_{1} / L\right)
$$

式中, $T_{\mathrm{b}}$ 为亮温 $(\mathrm{K}), K_{1} 、 K_{2}$ 为常量, 其中 $K_{1}=607.76 \mathrm{~mW} /\left(\mathrm{cm}^{2} \cdot \mathrm{sr} \cdot \mu \mathrm{m}\right), K_{2}=1260.56 \mathrm{~K}$. 
由于北京城区范围较小, 且采用的遥感图像晴空无云, 大气的影响程度在空间上可以近似认为是一致的, 从 而对地表温度空间相对分布影响也较小, 在这里忽略大气校正, 采用常见的比辐射率的方法计算地表温度 ${ }^{[20-21]}$ :

$$
T_{\mathrm{s}}=T_{\mathrm{b}}\left[1+\left(\lambda \cdot T_{\mathrm{b}} / \alpha\right) \ln \varepsilon\right]
$$

式中, $T_{\mathrm{s}}$ 为地表温度 $(\mathrm{K}), \lambda=11.5 \times 10^{6} \mathrm{~m}, \alpha=1.438 \times 10^{2} \mathrm{mK}, \varepsilon$ 为地表比辐射率, 采用 Van de Griend 的 $N D V I$ 估算法进行计算 ${ }^{[22]}$ :

$$
\varepsilon=1.009+0.047 \ln N D V I
$$

该经验关系只有 $N D V I$ 在 $0.16 \sim 0.74$ 之间时适用. 在这范围之外,采用土地利用类型进行比辐射率 $\varepsilon$ 纠正: 其中水体的比辐射率取 0.995 , 植被的比辐射率取 0.986 , 裸地土壤的比辐射率取 0.972 , 居民地的比 辐射率取 0.970 .

1.2.2 中粗分辨率卫星资料地表温度的反演 由于城市热环境大多注重的是温度相对强弱的空间分布特 征, 加之一般城市区域范围有限, 可以认为区域水汽状况一致, 在晴空无云状态下, 可直接利用亮温表征城 市热场的空间相对分布 ${ }^{[23-24]}$. NOAA/AVHRR 卫星亮温资料在对上海城市高温及热岛效应的研究中得到应 用 ${ }^{[25]}$. 本文对 NOAA/AVHRR 卫星资料采用第 4 热红外通道亮温来表征 $1 \mathrm{~km}$ 分辨率地表热场产品.

对 MODIS 卫星资料则直接采用了 MODIS $1 \mathrm{~km}$ 分辨率 $8 \mathrm{~d}$ 合成的温度产品 MOD $11 \mathrm{~A} 2$, 温度对应图层分别 为 LST_Day_1 $\mathrm{km}$ (白天温度) 和 LST_Night_1 km(夜间温度). 该产品是 MODIS 卫星的重要业务产品之一, 它对 陆地地表温度的监测能达到 $1 K(1 \sigma)$ 的精度,且能有效监测北京地区的城市热岛强度及季节变化 ${ }^{[16]}$.

对 FY-3A/MERSI 卫星资料则采用了 Jiménez-Muñoz 单窗算法 ${ }^{[26]}$ 进行温度反演得到 $250 \mathrm{~m}$ 分辨率地表 温度产品.

1.2 .3 热岛强度的计算 利用热岛强度指数可以反映城市热岛的强弱. 在这里, 采用叶彩华地表热岛强度 $U H I I$ 的计算方法来估算城市地表热岛强度 ${ }^{[27]}$, 即:

$$
U H I_{i}=T_{i}-\frac{1}{n} \sum_{i}^{n} T_{\text {crop }}
$$

式中, $U H I_{i}$ 为图象上第 $i$ 个象元所对应的热岛强度, $T_{i}$ 是地表温度, $n$ 为郊区农田内的有效象元数, $T_{\text {crop }}$ 为郊 区农田内的地表温度. 并按热岛强度值的大小,划分为 7 级热岛强度: 强冷岛、较强冷岛、弱冷岛、无热岛、弱 热岛、较强热岛和强热岛.

\section{2 结果与分析}

\section{1 水体类型的热场年变化}

利用 2006 年 MODIS 地表温度产品 (MOD11A2) 和 2005 年土地覆盖资料对北京地区不同季节、不同土 地覆盖类型的白天和夜晚地表季节平均温度进行了计算, 其中土地覆盖资料采用北京市 1:250000 2005 年 基础地理信息资料,把土地覆盖类型归并为林地、农田、草地 (绿地)、水体、建筑 5 大类别.

白天的计算结果 (图 1a) 显示: 北京地区春、夏、秋季 5 种地表覆盖类型的地表温度为水体 $<$ 林地 $<$ 农 田 $<$ 草地 $<$ 建筑, 冬季地表温度为水体 $<$ 林地 $<$ 建筑 $<$ 绿地 $<$ 农田, 表明在白天城市建筑相对郊区农田在 春、夏、秋季具有 “热岛效应”, 在冬季具有 “冷岛效应”, 这与王建凯等关于北京城区热岛 (冷岛) 的研究结论 一致 ${ }^{[28]}$; 而水体在一年四季白天温度均最低,具有降温作用, 这与刘娇妹等利用气象观测资料研究的结果一 致 ${ }^{[29]}$. 夜晚的计算结果 (图 1b) 显示: 各季草地 (绿地) 与建筑区地表温度最高, 由于绿地主要在城区分布, 因此它与建筑相对于郊区农田呈现“热岛效应”. 而水体在春季和夏季夜晚温度均低于其他类型, 表明水体 在暖热的夜晚具有降温效应, 到了秋季和冬季水体温度则高于农田和林地, 表明水体在寒冷的夜晚里具有 保温效应. 这与毛以伟等利用气象观测资料分析得到的南方三峡水体四季均具有白天降温、夜间增温效应 并不完全一致 ${ }^{[9]}$, 这很可能与北京所处半干旱地区与三峡处于湿润地区的不同水域气候效应有关 ${ }^{[8]}$.

\section{2 密云水库的热场日变化}

密云水库是北京最大的单一水体, 处于郊区密云县内. 近几年水体面积保持在 $70 \sim 90 \mathrm{~km}^{2}$, 蓄水量在 

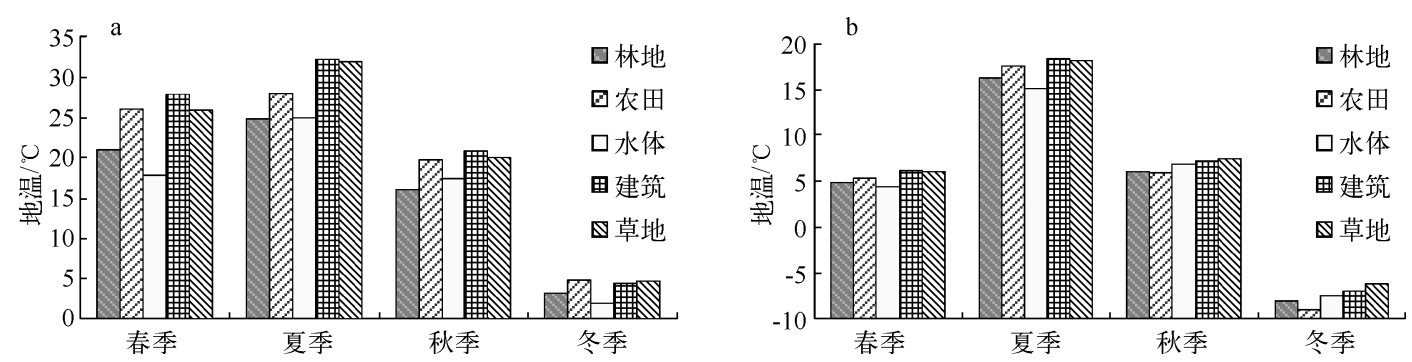

图 12006 年北京不同土地覆盖类型热场分布 (a. 白天, b. 夜晚)

Fig. 1 LST of different land cover types of Beijing in 2006 (a. Day, b. Night)

$10 \times 10^{8} \mathrm{~m}^{3}$ 左右, 其水体热场与周边其他类型相比具有明显差异. 在这里, 以 NOAA/AVHRR 资料来分析密 云水库水体在夏季和冬季的热场日变化.

2.2.1 夏季热场日变化 利用 NOAA/AVHRR 资料处理的 2006 年 8 月 21 日上午到夜间的北京地表亮温变 化显示: 上午 11:00 时 (图 2a) 和中午 13:00 时 (图 2b) 密云水库均处于低温区, 与周围及城区温度差异较 大; 傍晚 18:00 时 (图 2c) 密云水库与周围地表热场差异不大; 到夜晚 21:00 时 (图 2d) 密云水库与城区则均
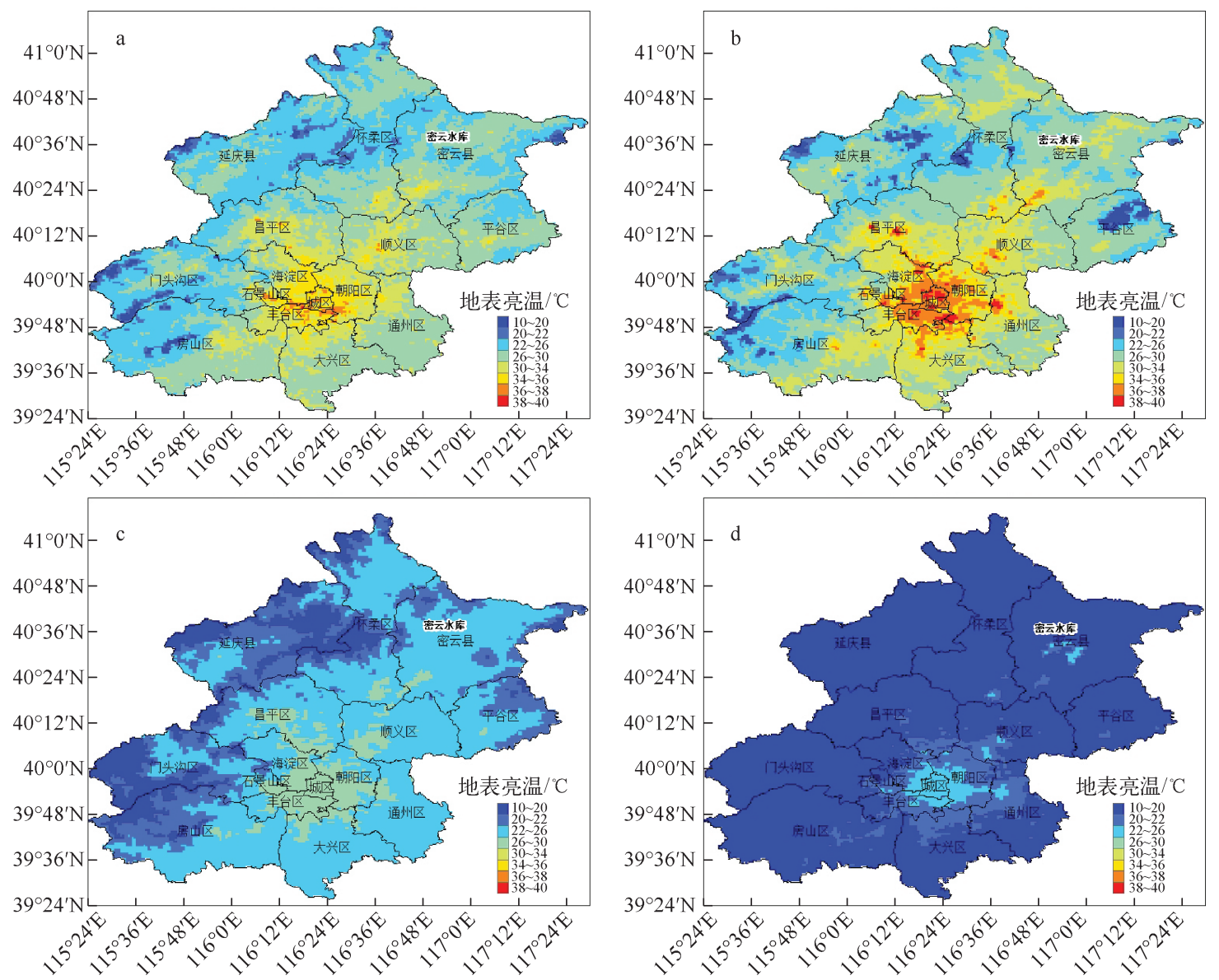

图 2 夏季 (2006-08-21) 北京地区密云水库地表亮温日变化(a. 11:00 时,b. 13:00 时,c. 18:00 时,d. 21:00 时)

Fig. 2 Daily variation of land surface brightness temperature of Miyun Reservoir of Beijing in summer(2006-08-21) (a. 3: 00GMT, b. 5: 00GMT, c. 10:00GMT, d. 13:00GMT) 
处于高温区. 这些监测结果表明:密云水库由于热容量大, 白天升温慢, 处于低温区, 具有 “冷湖效应” ; 夜晚 降温慢,与城中心并列为一高温区,具有 “暖湖效应”,这与吕雅琼等采用数值模拟方法得出夏季青海湖的冷 暖湖效应结论近似 ${ }^{[10]}$.

2.2.2 初冬未结冰状态 利用 2009 年 11 月 17 日 (水体未结冰) 中午 $14: 16$ 时的 NOAA18/AVHRR 气象卫星 资料对北京地区热岛强度监测显示:中午 (图 3a) 北京城区没有热岛效应,密云水库处于弱热岛区域; 夜晚凌 晨 (图 3b) 北京城区存在热岛效应, 以弱热岛和较强热岛等级为主, 密云水库处于强热岛区域. 这些监测结 果表明,初冬季节在水体未结冰状态下,白天和夜间密云水库具有“暖湖效应”,这与傅抱璞关于水域在不封 冻的情况下具有增温效应结论近似 ${ }^{[8]}$.
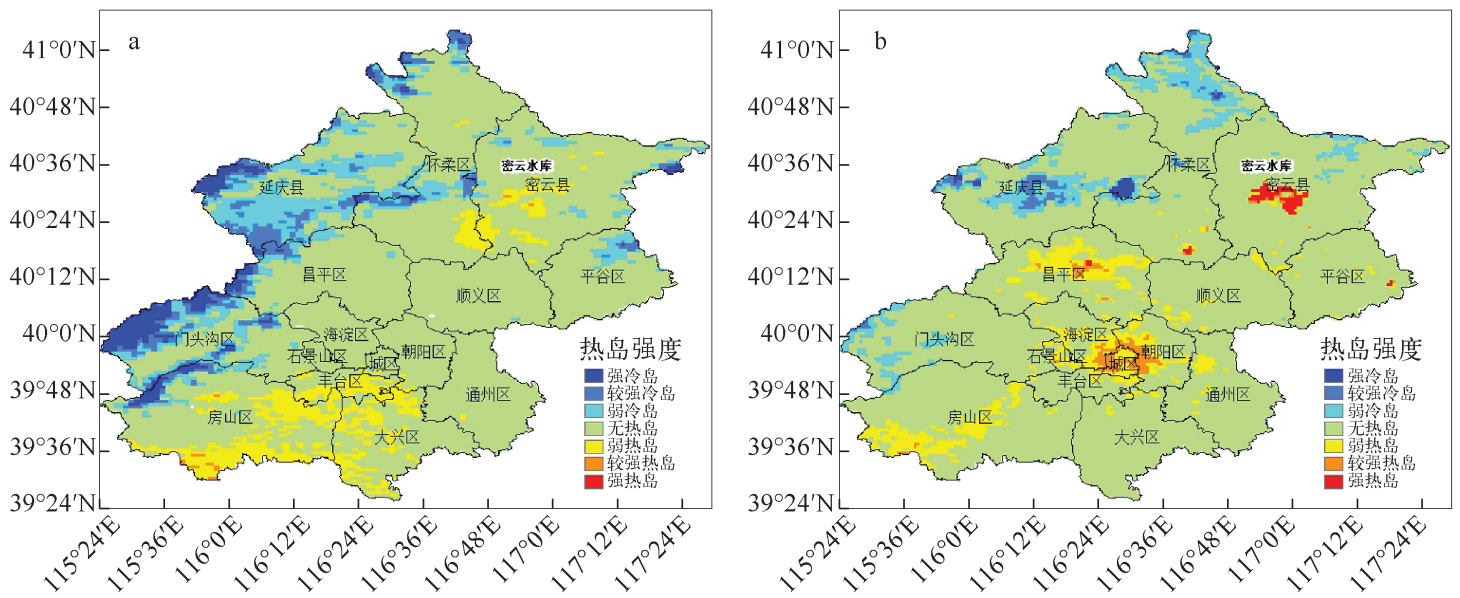

图 3 冬季 $(2009-11-17)$ 北京地区密云水库热岛强度日变化一一水体未结冰( a. 中午,b. 清晨)

Fig. 3 Daily variation of heat island intensity of Miyun Reservoir of Beijing under no-freezing condition in winter $(2009-11-17$ ) (a. noontime, b. early morning)

2.2.3 冬季结冰状态 利用 2011 年 2 月 15 日 (水体已结冰) 中午 13:59 时的 NOAA18 气象卫星资料对北京 地区热岛温度监测显示 (图 4) : 中午时分 (图 4a) 北京城区没有热岛效应,密云水库处于强冷岛区域; 夜晚凌
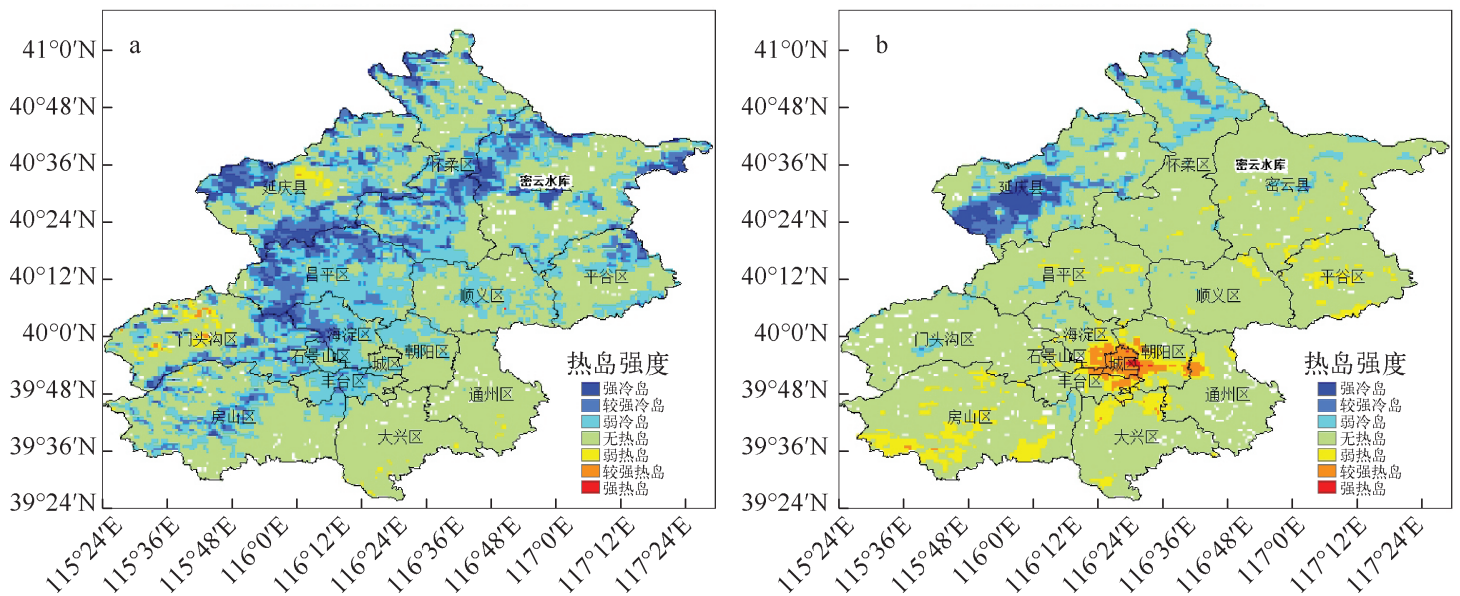

图 4 冬季 (2011-02-15) 北京地区密云水库热岛强度日变化一一水体结冰( a. 中午,b. 凌晨)

Fig. 4 Daily variation of heat island intensity of Miyun Reservoir of Beijing under freezing condition in winter(2011-02-15) (a. noontime, b. early morning) 
晨 (图 4b) 北京城区存在明显的热岛效应, 而密云水库与周边环境同处于无热岛区域. 这些监测结果表明, 在冬季水体结冰的情况下,白天密云水库具有“冷湖效应”,夜晚水体无明显冷暖效应.

\section{3 城区水体的热环境效应}

以北京城六区内典型水体昆明湖、中南海 (含前海、后海、西海、北海与中南海)、紫竹院湖、玉渊潭湖、龙 潭湖等为例, 分析这些处于城区内的不同尺度水体的城市热环境效应. 利用 2008 年 8 月 2 日 Landsat-TM5 卫星图像估算的中南海、玉沸潭湖、昆明湖、龙潭湖和紫竹院湖等各水体面积分别为 $122 、 52 、 195 、 15$ 和 $11 \mathrm{hm}^{2}$, 其中昆明湖面积最大, 紫竹院湖面积最小.

2.3.1 城区水体的“冷岛效应” 应用 2009 年 6 月 25 日 10 时 45 分的 FY-3A/MERSI 气象卫星资料处理制 作的北京城六区地表热岛强度监测图显示: 上午近 11:00时 (图 5a), 北京城六区出现弱热岛现象, 局部地区 如前门、首钢小区出现较强热岛, 而昆明湖、中南海等水体为弱冷岛或较强冷岛, 龙潭湖、紫竹院湖和玉波潭 湖水体为无热岛区域. 到了中午近 13:00 时 (图 5b), NOAA18 卫星监测的城六区热岛范围明显扩大, 强度增 强,昆明湖、中南海、龙潭湖、紫竹院湖和玉渊潭湖等水体处于弱冷岛或无热岛区域,而昆明湖的 “冷岛” 效应 较其他水体更为明显. 利用 2008 年 8 月 2 日的 Landsat-TM5 监测的地表热岛强度图 (图 6) 显示: 上午 10:40 时, 北京城六区普遍出现弱热岛, 局部地区出现较强热岛, 相比初夏 6 月 25 日热岛效应更为明显, 但各水体 多呈弱冷岛或无热岛现象, 其中昆明湖、中南海、玉浑潭湖、紫竹院湖呈弱冷岛, 而面积较小的龙潭湖呈无热 岛状态. 上述监测结果表明: 无论何种卫星资料的处理结果都显示城区水体尤其是大面积的水体是降低城 市地表热岛现象的重要来源.

2.3.2 城区水体对周边热环境的影响 为分析城区内昆明湖、玉滟潭湖、中南海、龙潭湖和紫竹院湖等水体 对周边地区热环境的影响, 基于缓冲区技术, 以 $500 \mathrm{~m}$ 为半径缓冲区, 来分析每个水体斑块对周边建筑区热 环境的影响, 并选择城区内较大面积的天坛公园为例, 代表城区内绿地对周边热环境的影响进行对比 分析.

利用 2008 年 8 月 2 日 Landsat-TM5 提取的昆明湖、玉洲潭湖、中南海、龙潭湖和紫竹院湖等水体、水体 缓冲区域及周边土地利用类型. 可以看出, 除昆明湖周边有较多植被外, 其它水体周围分布着大面积的城区 建筑. 天坛公园为一大片绿地, 周围也被城区建筑包围 (图 7). 根据 Landsat-TM5 卫星资料估算的地表温度, 计算各水体和绿地平均温度及水体和绿地缓冲距离范围内的建筑区平均地表温度,结果见表 1 .

面积最大的昆明湖水温最低 $\left(24.7^{\circ} \mathrm{C}\right)$, 而面积最小的紫竹院湖水温 $\left(25.3^{\circ} \mathrm{C}\right)$ 与面积排第二的中南海水 温接近 $\left(25.4^{\circ} \mathrm{C}\right)$, 而面积仅大于紫竹院湖的龙潭湖水温最高 $\left(25.7^{\circ} \mathrm{C}\right)$, 表明水体的水温与大小可能没有直 接关系. 而各水体平均温度 $\left(25.2^{\circ} \mathrm{C}\right)$ 明显低于天坛公园温度 $\left(26.5^{\circ} \mathrm{C}\right)$, 表明水体较绿地具有更明显的“冷 岛”效应(表 1).

各水体缓冲区范围内的建筑区地表温度均明显高于水体温度. 就平均状况来看, $0 \sim 100 \mathrm{~m}$ 内地表温度 最低, 平均为 $26.6^{\circ} \mathrm{C}$, 距离水体越远, 地表温度呈增高趋势, $300 \sim 400 \mathrm{~m}$ 和 $400 \sim 500 \mathrm{~m}$ 内分别为 $27.8^{\circ} \mathrm{C}$ 和 $27.9^{\circ} \mathrm{C}$, 但超过 $300 \mathrm{~m}$ 后, 建筑区地表温度基本不再有明显变化 $\left(0.2^{\circ} \mathrm{C}\right.$ 之内 $)$ 表明. 天坛公园绿地周围 $100 \mathrm{~m}$ 范围内建筑区地表温度为 $28.1^{\circ} \mathrm{C}$, 低于 $100 \mathrm{~m}$ 之外范围内建筑区地表温度 (大于 $28.4^{\circ} \mathrm{C}$ ), 距离超过 $100 \mathrm{~m}$ 后,建筑区地表温度不再有明显变化.

由前面分析可知, 水体周围 $300 \mathrm{~m}$ 之外、绿地周围 $100 \mathrm{~m}$ 之外的建筑区地表温度变化很小, 因此以 400 $500 \mathrm{~m}$ 该区域内的建筑区代表不受水体或绿地降温影响的正常建筑区, 其它区域内建筑区地表温度与其进 行距平计算,就可得到水体及天坛公园绿地周围 0 400 m 建筑区地表的降温幅度 (表 2).

随距水体距离增加, 建筑地温降温幅度呈下降趋势, 各水体周围建筑地温平均下降值在 $0 \sim 100 、 100$ 200 和 $200 \sim 300 \mathrm{~m}$ 分别为 $1.2 、 0.6$ 和 $0.4^{\circ} \mathrm{C}$, 而 $300 \sim 400 \mathrm{~m}$ 已几乎没有降温效应 $\left(0.1^{\circ} \mathrm{C}\right.$ ) (表 2 ). 另外各水 体降温还有个体差异, 中南海仅在 $100 \mathrm{~m}$ 范围内建筑区地表温度有所下降. 绿地也仅在 $100 \mathrm{~m}$ 范围内对建筑 区地表温度有影响, 降温幅度为 $0.4^{\circ} \mathrm{C}$, 小于水体周边 $100 \mathrm{~m}$ 内的降温幅度 $1.2^{\circ} \mathrm{C}$. 这些结果表明: 由于水体 的存在, 其周边最大 $300 \mathrm{~m}$ 范围内的建筑区地表温度下降, 而绿地周边 $100 \mathrm{~m}$ 范围内的建筑区地表温度下 降, 城市水体对周边环境热场的影响程度和范围大于城市绿地. 

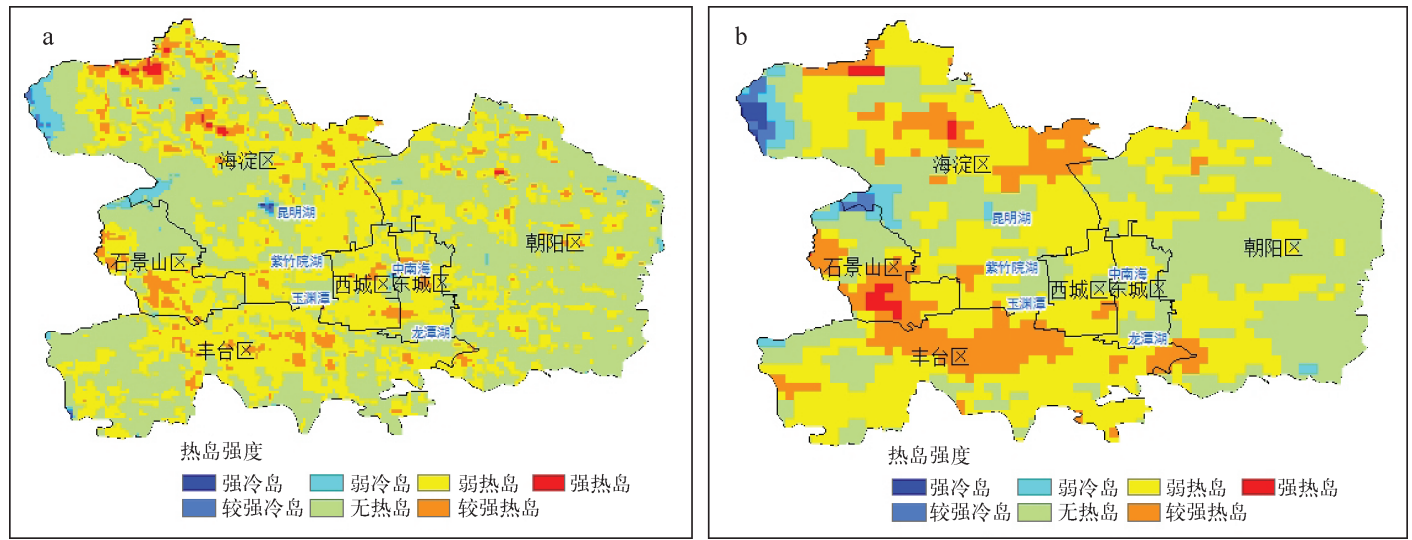

图 5 北京城区 2009 年 6 月 25 日地表热岛强度遥感监测图 (a. 10:45, b. 12:57)

Fig. 5 Land surface island heat intensity of Beijing urban area in June 25th,2009 (a. 2:45 GMT, b. 4:57 GMT)

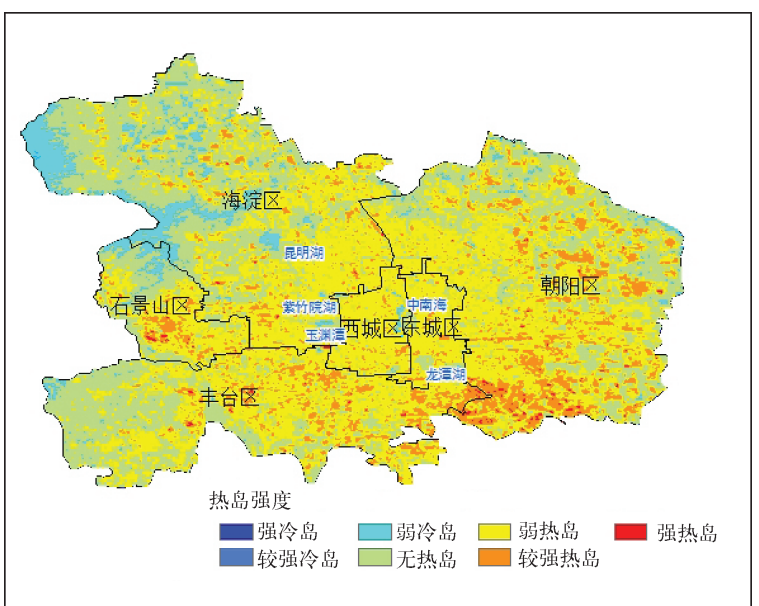

图 6 北京城区 2008 年 8 月 2 日地表热岛强度

Fig. 6 Land surface heat island intensity of Beijing urban in Aug. 2nd,2008

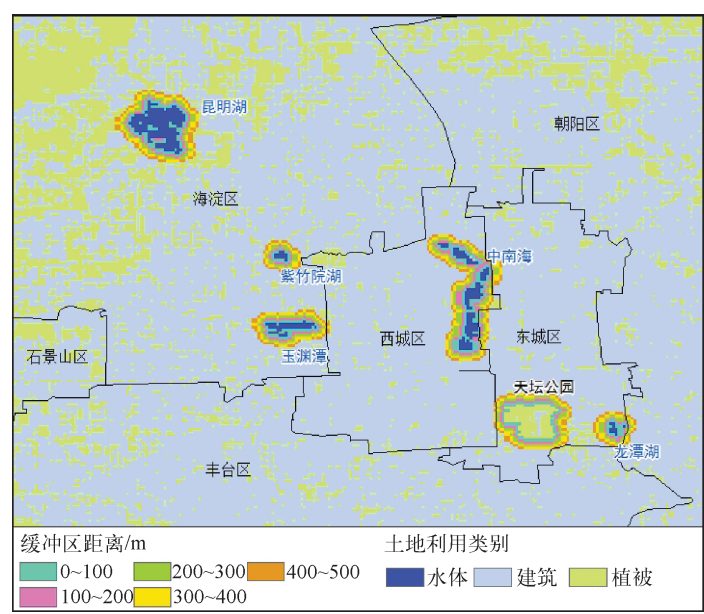

图 7 城六区主要水体缓冲区及土地利用类型 (2008 年 8 月 2 日)

Fig. 7 Buffer zones of urban water bodies and landuse types (Aug. 2nd, 2008)

表 1 主要水体及绿地温度及缓冲区范围内的建筑地表温度 $\left({ }^{\circ} \mathrm{C}\right)$

Tab. 1 Land surface temperature of building area in buffer zones of water bodies and green land

\begin{tabular}{cccccccc}
\hline \multirow{2}{*}{ 缓冲区范围 $/ \mathrm{m}$} & \multicolumn{9}{c}{ 水体 } & \multicolumn{2}{c}{ 绿地 } \\
\cline { 2 - 6 } & 中南海 & 龙潭湖 & 玉渊潭湖 & 昆明湖 & 紫竹院湖 & 平均 & 天坛公园 \\
\hline \multirow{2}{*}{$\leqslant 0$ (水体或绿地) } & 25.4 & 25.7 & 24.8 & 24.7 & 25.3 & 25.2 & 26.5 \\
$0 \sim 100$ & 27.2 & 26.8 & 26.2 & 26.1 & 26.9 & 26.6 & 28.1 \\
$100 \sim 200$ & 27.9 & 27.2 & 26.7 & 26.6 & 27.7 & 27.2 & 28.6 \\
$200 \sim 300$ & 28.1 & 27.5 & 27.2 & 26.8 & 27.9 & 27.5 & 28.5 \\
$300 \sim 400$ & 28.0 & 27.9 & 27.7 & 27.2 & 28.2 & 27.8 & 28.4 \\
$400 \sim 500$ & 28.0 & 28.0 & 27.9 & 27.3 & 28.1 & 27.9 & 28.5 \\
\hline
\end{tabular}


表 2 主要水体缓冲区范围建筑区降温幅度 $\left({ }^{\circ} \mathrm{C}\right)$

Tab. 2 Temperature cooling values of buildings areas of water bodies buffer zones

\begin{tabular}{ccccccccc}
\hline \multirow{2}{*}{ 缓冲区范围 $/ \mathrm{m}$} & \multicolumn{9}{c}{ 水体 } & & 绿地 \\
\cline { 2 - 7 } & 中南海 & 龙潭湖 & 玉渊潭湖 & 昆明湖 & 紫竹院湖 & 平均 & 天坛公园 \\
\hline $0 \sim 100$ & -0.8 & -1.2 & -1.7 & -1.2 & -1.2 & -1.2 & -0.4 \\
$100 \sim 200$ & -0.1 & -0.8 & -1.2 & -0.7 & -0.4 & -0.6 & 0.1 \\
$200 \sim 300$ & 0.1 & -0.5 & -0.7 & -0.5 & -0.2 & -0.4 & 0 \\
$300 \sim 400$ & 0 & -0.1 & -0.2 & -0.1 & 0.1 & -0.1 & -0.1 \\
\hline
\end{tabular}

\section{3 结论}

通过对地表水体的热环境效应分析得知, 水体的热场分布与其它类型差异较大, 城市水体对周边建筑 区热环境存在着明显降温效应,对降低城市热岛效应具有明显作用. 根据上述分析,初步得到以下结论:

1) 卫星资料能有效监测北京水体温度的四季变化:水体在白天具有降温效应,在秋季和冬季寒冷的夜 晚里具有保温作用,在春季和夏季夜晚具有降温作用.

2 ）密云水库在夏季白天具有 “冷湖效应”, 夜晚具有 “暖湖效应”; 冬季在水体未结冰状态下, 白天和夜 间水体均具有“暖湖效应”,在结冰状态下,白天具有“冷湖效应”,晚上则无冷暖效应.

3 ）遥感监测显示城区水体没有地表热岛现象出现,大面积的水体更易出现 “冷岛” 效应, 是降低城市热 岛效应的重要途径.

4) 由于水体存在, 其周边最大 $300 \mathrm{~m}$ 范围内的建筑区地表温度均有下降, 其中各水体 $100 \mathrm{~m}$ 范围内平 均下降 $1.2^{\circ} \mathrm{C} ; 100 \sim 200 \mathrm{~m}$ 内下降 $0.6^{\circ} \mathrm{C} ; 200 \sim 300 \mathrm{~m}$ 内下降 $0.4^{\circ} \mathrm{C}$. 而绿地周围仅在 $100 \mathrm{~m}$ 范围内的建筑区 地表温度有所下降,平均下降 $0.4^{\circ} \mathrm{C}$.

\section{4 参考文献}

[ 1 ] Arnfield AJ. Two decades of urban climate research: A review of turbulence, exchanges of energy and water, and the urban heat island. International Journal of Climatology, $2003,23(1): 1-26$.

[2] 胡 非,洪钟祥,雷孝恩. 大气边界层和大气环境研究进展. 大气科学, 2003,27(4):712-728.

[ 3 ] 徐 敏,蒋维楣,季崇萍等. 北京地区气象环境数值模拟试验. 应用气象学报,2002,13(特刊):61-68.

[ 4 ] Saaroni H, Ziv B. The impact of a small lake on heat stress in a Mediterranean urban park: the case of Tel Aviv, Israel. International Journal of Biometeorology, 2003 ,47(3) : 156-165.

[ 5 ] 郭 勇,龙步菊,刘伟东等. 北京城市热岛效应的流动观测和初步研究.气象科技,2006,34(6):656-661.

[6] 佟 华, 刘辉志, 李延明等. 北京夏季城市热岛现状及楔形绿地规划对缓解城市热岛的作用. 应用气象学报, 2005, 16(3) :357-366.

[ 7 ] 宫阿都, 陈云浩, 李 京等. 北京市城市热岛与土地利用/覆盖变化的关系研究. 中国图象图形学报, 2007,12(8): 1476-1482.

[8] 傅抱璞.我国不同自然条件下的水域气候效应. 地理学报, 1997,52(3):246-253.

[9] 毛以伟,陈正洪,王 玨等.三峡水库坝区蓄水前水体对水库周边气温的影响. 气象科技,2005,33(4):334-339.

[10］吕雅琼,杨显玉,马耀明. 夏季青海湖局地环流及大气边界层特征的数值模拟. 高原气象,2007,26(4):686-692.

[11] 赵 林, 陈玉春, 吕世华等. 金塔绿洲解放村水库夏季晴天水文气象效应的数值模拟. 高原气象, 2010,29(6): 1414-1422.

[12］柳孝图,陈恩水,余德敏. 城市热环境及其微热环境的改善. 环境科学, 1997,18(1):54-58.

[13] 杨 凯, 唐 敏, 刘 源等. 上海中心城区河流及水体周边小气候效应分析. 华东师范大学学报, 2007, (9): 105-114.

[14] 李书严,轩春怡,李 伟等. 城市中水体的微气候效应研究. 大气科学, 2008,32(3) :552-560.

[15] 轩春怡,王晓云, 蒋维相等. 城市中水体布局对大气环境的影响. 气象, 2010,36(12):94-101.

[16] Prata AJ. Land surface temperature derived from the Advanced Very High Resolution Radiometer and Along-Track Scan- 
ning Radiometer 1. theory. Journal of Geophysical Research, 1993 ,98: 16689-16702.

[17］王建凯,王开存,王普才. 基于 MODIS 地表温度产品的北京城市热岛(冷岛)强度分析. 遥感学报,2007,11(3)： 330-339.

［18］杨 军,董超华,卢乃锰等. 中国新一代极轨气象卫星一一云三号.气象学报,2009,67(4):501-509.

[19] Chander G, Markham B. Revised Landsat-5 TM radiometric calibration procedures and postcalibration dynamic ranges. IEEE Transactions on Geoscience and Remote Sensing,2003,41(11) : 2674-2677.

[20] Artis DA, Carnahan WH. Survey of an emissivity variability in thermographs of urban areas. Remote Sensing of Environment, $1982,12(4): 313-329$.

[21] 彭 静,刘伟东,龙步菊等. 北京城市热岛的时空变化分析. 地球物理学进展,2007,22(6): 1942-1947.

[22] Van de Griend AA, Owe M. On the relationship between thermal emissivity and the Normalized Difference Vegetation Index for natural surfaces. International Journal of Remote Sensing ,1993,14: 1119-1131.

[23] 许军强,刘嘉宜,刑立新等. 长春市热岛效应的时空演变研究. 环境保护科学, 2007,33(3):8-10.

[24］陈云浩,王 洁, 李晓兵. 夏季城市热场的卫星遥感分析. 国土资源遥感,2002,4:55-59.

[25] 丁金才,张志凯,奚 红等.上海地区盛夏高温分布和热岛效应的初步研究. 大气科学,2002,26(3):412-420.

[26] Jimenez-Munoz JC, Sobrino JA. A generalized single channel method for retrieving land surface temperature from remote sensing data. Journal of Geophysical Research,2003,108(22):4688-4695.

[27] 叶彩华,刘勇洪,刘伟东等. 城市地表热环境遥感监测指标研究及应用. 气象科技,2011,39(1):95-101.

[28］王建凯,王开存,王普才. 基于 MODIS 地表温度产品的北京城市热岛(冷岛)强度分析. 遥感学报,2007,11 (3)： 330-339.

[29］刘娇妹,杨志峰. 北京市冬季不同景观下垫面温湿度变化特征. 生态学报,2009,29(6):3241-3252. 